\title{
M. Holiak,
}

V. Revka, PhD,

IL. Chyrko, PhD,

O. Trygubenko,

Yu. Chaikovsky

NASU Institute for Nuclear Research, 47 Nauky Ave., Kyiv, Ukraine, 03028, e-mail: nickgolyak@gmail.com

\section{POSSIBILITY OF A LIFE-TIME EXTENSION FOR WWER-1000 REACTOR PRESSURE VESSELS BEYOND THE DESIGN PERIOD}

\begin{abstract}
М.Г. Голяк, В.М. Ревка, Л.І. Чирко, О.В. Тригубенко, Ю.В. Чайковський. Можливість подовження періоду безпечної експлуатації корпусів реакторів ВВЕР-1000 в понадпроектний термін. Подовження проектного терміну експлуатації корпусів реакторів діючих в Україні атомних електростанцій з реакторами типу ВВЕР-1000 є актуальним питанням сьогодення. Для подовження терміну експлуатації в понад проектний період необхідно оцінити механічні властивості і критичну температуру крихкості $T_{K}$ матеріалу корпусу реактора, а також виконати розрахунки на опір крихкому руйнування. Для контролю за змінами механічних властивостей використовуються результати випробувань зразків-свідків, які виготовлені з того ж металу, що і корпус реактора. На сьогоднішній день отримані дозові залежності температури $\mathrm{T}_{\mathrm{K}}$ металу зварних швів у діапазоні флюенсів швидких $(E \geq 0,5 \mathrm{MeB})$ нейтронів $(F)$, що відповідають терміну експлуатації корпусу реактора більше 40 років. В роботі проведено аналіз даних зразків-свідків для корпусів реакторів ВВЕР-1000, зварні шви яких мають підвищений вміст нікелю та марганцю і схильні до значного радіаційного окрихчування. Зразки-свідки опромінені в діапазоні флюенсів, максимальне значення якого перевищує проектний флюенс нейтронів $57 \cdot 10^{22} \mathrm{M}^{-2}$. Аналіз показав, що експериментальні залежності температури $T_{K}$ від флюенсу нейтронів для зварних швів узгоджуються з проектною моделлю окрихчування з показником ступеня $1 / 3$. Результати порівняння критичної температури крихкості $з$ максимально допустимим значенням $T_{K}^{a}$ свідчать про можливість подовження терміну безпечної експлуатації корпусів реакторів ВВЕР-1000 в понадпроектний період.

Ключові слова: флюенс швидких нейтронів, зразки-свідки, понадпроектний термін експлуатації, корпус реактора

M. Holiak, V. Revka, L. Chyrko, O. Trygubenko, Yu. Chaikovsky. Possibility of a life-time extension for WWER-1000 reactor pressure vessels beyond the design period. At present a life-time extension for WWER-1000 reactor pressure vessels is an actual issue in Ukraine. For a decision about the life-time extension it is needed to assess mechanical properties and the critical brittleness temperature $T_{K}$ for the RPV materials as well as to perform the brittle strength calculations. The surveillance test data for the reactor pressure vessel in question are used for an estimation of changes in the mechanical properties. For today dose dependences of the temperature $T_{K}$ for weld metal in the fluence range of fast $(E \geq 0.5 \mathrm{MeV})$ neutrons, corresponding to the RPV lifetime more than 40 years, have been obtained. This paper analyzes the surveillance test data for the WWER-1000 reactor pressure vessels, whose welds have a high content of nickel and manganese and are prone to considerable radiation embrittlement. The surveillance specimens have been irradiated within the fluence range, the maximum value of which exceeds the design fluence $57 \cdot 10^{22} \mathrm{~m}^{-2}$. The analysis has shown that the experimental dependences of the temperature $T_{K}$ on the neutron fluence for welds are consistent with the design embrittlement model with the exponent of 1/3. The results of comparison between the critical brittleness temperature and the maximum allowable value $T_{K}^{a}$ indicate a possibility of the life-time extension for WWER-1000 reactor pressure vessels beyond the design period.

Keywords: fast neutrons fluence, surveillance specimens, long-term operation, reactor pressure vessel
\end{abstract}

\section{Introduction}

There are currently 13 WWER-1000 reactors operating in Ukraine, of which only five have not completed their design safe life-time of 30 years. The design life-time of the WWER-1000 reactor vessel (RPV) is 40 years. For the metal of the five reactor vessels, when the unit reached its 30-year operating life-time, calculations were made for brittle fracture resistance and the design life-time was confirmed. Since the results of testing of metal specimens samples of some RPV have obtained values of critical brittleness temperatures at beyond design fluence of fast $(E \geq 0.5 \mathrm{MeV})$ neutrons, the question arises about the substantiation of the possibility of operation of reactor vessels in the beyond design period. 


\section{Analysis of published data and problem definition}

Radiation embrittlement of vessel steel is a major factor that limits the nuclear reactor life-time. The main mechanism of embrittlement is to prevent the movement of dislocations by defective structures that develop in the volume of material due to irradiation. Two classes of nanostructured fractions are considered to be the main contributors to the development of embrittlement. First, they are clusters of soluble atoms, such as $\mathrm{Cu}, \mathrm{Ni}$, and $\mathrm{Mn}$, so-called precipitates, and secondly, matrix damage, which are interpreted as point-defect clusters [1].

For the first class of fractions, Cu-enriched (CRP) and Mn-Ni (MNP) enriched precipitates. The formation of the latter, which may not contain $\mathrm{Cu}$, is supported at high concentrations of $\mathrm{Ni}, \mathrm{Mn}$ and $\mathrm{Si}$. In this case, MNP without $\mathrm{Cu}$ are detected only at sufficiently high neutron fluence.

It is thought that precipitates enriched in $\mathrm{Mn}$ and $\mathrm{Ni}$ will grow to larger volumes after birth. On this basis, they are often referred to as late blooming phases (LBP) [2]. First of all, it concerns welds with high content of nickel and manganese, irradiated to high fluences, in which the effect of accelerated brittlement (so-called late blooming effect).

\section{The purpose and objectives of the study}

Regulatory model ПНАЕ- $-7-002-86$ [3] does not provide the acceleration of radiation embrittlement at high fluence of fast $(E \geq 0.5 \mathrm{MeV})$ neutrons.

To test the possibility of using the regulatory model, it is necessary to analyze the experimental dose dependences of the critical temperature of the brittleness of the RPV metal irradiated to beyond design fluence of fast neutrons. The results obtained will reveal the limits of safe operation of the reactor vessel, the material of which is characterized by high content of nickel and manganese.

\section{The program of specimens}

The main source of information on changes in the material properties of the reactor vessel under NPP operating conditions is the specimens program. The latter are made of the same metal as the reactor vessel in which they are irradiated. The test results of the samples in the initial state (control samples) are compared with the results of tests of samples withdrawn from the reactor after irradiation.

Container assemblies of specimens of the first three sets are bunk. The upper tier is irradiated by a flow of fast $(E \geq 0.5 \mathrm{MeV})$ neutrons close to the flux to the wall opposite the active zone. The neutron flux to the lower tier is approximately twice as powerful (Fig. 1).

The state of metal of the upper tier specimen characterizes the current state of the reactor vessel wall, the lower tier specimen serves to predict the metal state of the reactor vessel wall. Predictive data for higher neutron fluence are obtained using the technology of reconstruction of the lower halves of the

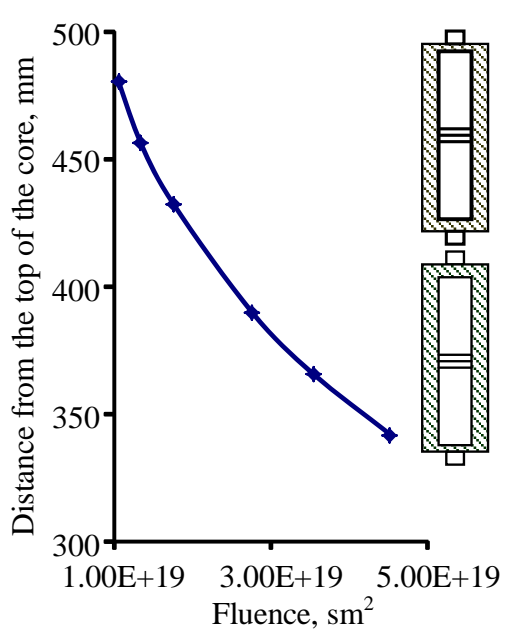

Fig. 1. The distribution of neutron fluences by the height of the container assembly specimens of the lower tier. Reconstruction of the specimens from the half of the subjects tested for shock and three-point bending of the samples is also used to obtain homogeneously irradiated groups of samples, the tests of which provide the representative data.

According to the design documentation for 40 years of operation, the wall of the reactor vessel under welding will accumulate fast neutron fluence of $\sim 57 \cdot 10^{22}$ neutron $/ \mathrm{m}^{2}$. In practice, due to the formation of a core with reduced neutron leakage, the power of their flow to the wall is reduced to about $1 \cdot 10^{22}$ neutron $/ \mathrm{m}^{2}$ per fuel campaign. Thus, there is a potential possibility of extending the reactor vessel's life for more than 40 years, but this statement needs to be substantiated.

A prerequisite for safe operation of WWER-1000 is to maintain the temperature reserve of the viscosity of the material of reactor vessel. The safety of operation of the WWER-1000 vessel is ensured only if the critical brittleness temperature $T_{K}$ is lower than the maximum permissible critical brittleness temperature $T_{K}^{a}$ in all operating modes. The latter is obtained as a result of calculations to 
resist brittle fracture, taking into account not only normal operating conditions, but also different scenarios of emergencies.

In order to evaluate the possibility of safe operation of the reactor vessel in the beyond design period, the results of testing of Sharpee-type test specimens for weld metal with high nickel and manganese content were analyzed.

\section{Test methodology}

Testing of the specimens is carried out in the specialized laboratory of the Nuclear Research Institute of the National Academy of Sciences of Ukraine, which is equipped with security cameras with remotely controlled equipment, which regularly undergoes metrological verification.

For the tests, reconstructed from the lower half of the specimens, which were formed after the impact test or the three-point bend, were used. The reconstruction involves welding half of the end extensions (the so-called shanks) to the ends, with subsequent notching on the corresponding surface of the sample.

Shock bending tests of reconstructed Sharpie specimens $(10 \times 10 \times 55 \mathrm{~mm})$ shall be carried out in accordance with the requirements of DSTU EN 10045-1:2006. The test uses a KMD-30D pendulum with remote control, which is installed in a protective, so-called "hot" chamber. Before testing, the samples are kept at a predetermined temperature for 20 minutes in an integrated temperature chamber that ensures uniform cooling or heating of the sample. Temperature stability is $\pm 2{ }^{\circ} \mathrm{C}$. The test temperature is chosen so that most of the samples are tested at temperatures corresponding to the criterion levels of toughness in the transition area and the upper shelf of the Charpy curve.

For each sample, the toughness, the transverse extension on the face opposite the incision, and the type of fracture characterized by the fraction of the viscous component in the fracture of the sample are determined.

The temperature dependences of the toughness are approximated by the function of hyperbolic tangent of this form [3]:

$$
K C V=\left(\frac{U S E}{2}\right) \cdot\left(1+\tanh \left(\frac{T-T_{0}}{C}\right)\right),
$$

where $K C V$ - impact strength (specific fracture work), USE - the viscosity value on the upper shelf of the $K C V$ temperature dependence, $T$ - test temperature; $T_{0}$ - the temperature corresponding to the value of impact strength $\frac{U S E}{2} ; C$-parameter characterizing the slope of the $K C V$ temperature dependence.

Upper shelf impact toughness is defined as the average value for samples with completely viscous fracture. The parameters $T_{0}$ and $C$ are determined by the least squares method for the case of nonlinear dependence.

The graphs obtained are the initial information for determining the critical brittleness temperature $T_{K F}$ according to the requirements of PNAE G-7-002-86 norms. The shift of the critical brittleness temperature $\Delta T_{F}$ is determined by the following formula:

$$
\Delta T_{F}=T_{K F}-T_{K I},
$$

where $\Delta T_{F} \geq 0, T_{F}$-temperature of brittleness of material after irradiation, $T_{K I}$ - the temperature of the brittleness of the material in the original state, obtained for irradiated (prior to radiation).

The critical temperature of the metal brittleness $T_{K}$ of the reactor vessel is determined by the formula:

$$
T_{K}=T_{K 0}+\Delta T_{F},
$$

where $T_{K 0}$ - the value of the initial critical brittleness temperature specified in the passport for the reactor vessel for this type of metal (weld metal or base metal).

The normative dose dependence of the critical temperature shift of brittleness according to PNAE $\mathrm{G}-7-002-86$ is described by the following equation:

$$
\Delta T_{F}=A_{F}\left(F / 10^{22}\right)^{1 / 3},
$$


where $F$ - fast neutron fluence, $A_{F}$ is the radiative coefficient of radiation, which is found by the method of least squares. To ensure the necessary conservatism, a $95 \%$ confidence limit is calculated, which is calculated in accordance with the requirements of NAEK standart 087:2015 [4]:

$$
T_{K}(95 \%)=T_{K 0}+\Delta T_{F}+M,
$$

where $T_{K 0}$ - the critical temperature of brittleness in the initial state of the material, determined at the factory and shown in the passport to the reactor vessel, $M$ is a temperature margin that takes into account $95 \%$ confidence in the uncertainty of the estimate $\Delta T_{K}$ due to material heterogeneity and irradiation conditions; $M$ - equals twice the standard deviation for the generalized dependence $\Delta T_{F}(F)$ for all reactor vessels of Ukraine's NPPs and is $11^{\circ} \mathrm{C}$.

\section{Influence of neutron irradiation on metal embrittlement}

The results of investigations of the weld metal specimens of the reactor vessel, which have a high content of nickel and manganese, are used in the work. The Table shows the chemical composition of the metal of the samples of analyzed reactor vessels.

Chemical composition of test materials (\% by weight)

\begin{tabular}{c|c|c|c|c|c|c|c|c|c}
\hline Unit $^{*}$ & $\mathrm{C}$ & $\mathrm{Mn}$ & $\mathrm{P}$ & $\mathrm{S}$ & $\mathrm{Si}$ & $\mathrm{Ni}$ & $\mathrm{C} \Gamma$ & $\mathrm{Mo}$ & $\mathrm{Cu}$ \\
\hline $\mathrm{A} 1$ & 0.06 & 0.67 & 0.008 & 0.008 & 0.32 & 1.55 & 1.77 & 0.59 & 0.03 \\
\hline $\mathrm{A} 2$ & 0.06 & 0.65 & 0.009 & 0.014 & 0.33 & 1.70 & 1.77 & 0.59 & 0.06 \\
\hline $\mathrm{A} 3$ & 0.07 & 0.86 & 0.009 & 0.010 & 0.27 & 1.60 & 1.86 & 0.67 & 0.08 \\
\hline $\mathrm{A} 4$ & 0.06 & 0.74 & 0.005 & 0.005 & 0.30 & 1.72 & 1.88 & 0.62 & 0.06 \\
\hline $\mathrm{A} 5$ & 0.09 & 1.0 & 0.007 & 0.01 & 0.25 & 1.77 & 1.74 & 0.65 & 0.05 \\
\hline $\mathrm{A} 6$ & 0.06 & 0.93 & 0.006 & 0.007 & 0.26 & 1.88 & 1.80 & 0.65 & 0.02 \\
\hline
\end{tabular}

Fig. 2 presents a comparison of the dependences of the critical brittleness temperature with the maximum allowable value calculated as a result of the calculations of the brittle fracture resistance for each of the metals analyzed. Dependencies $T_{K}(F)$ are used with $95 \%$ confidence in proper conservatism.

As can be seen from Fig. 2, only one metal sufficiently sensitive to irradiation, namely the A3 unit (0.86 wt. \% Mn, 1.6 wt. \% Ni) (Fig. 2 c). The irradiation embrittlement coefficient for this metal is $27 \mathrm{C}$. This may be due to the copper content of $0.08 \mathrm{wt}$. \% and phosphorus (0.009 wt. \%). It is these elements, and most of all phosphorus, that affect the rate of embrittlement under irradiation at $290{ }^{\circ} \mathrm{C}$.

The reactor vessel of the A6 unit, which contains the highest amount of phosphorus $(0.88 \%$ by weight) along with high manganese content ( $0.93 \%$ by weight), demonstrates the possibility of prolonging the safe life-time at least prior to the accumulation of the fast neutron fluence by reactor vessel wall at least $60.10^{22}$ neutron $/ \mathrm{m}^{2}$ at the level of seam № 3 .

After the phosphorus atoms are exhausted by settling them at the boundaries of grains and subgrains, the formation and growth of precipitates based on Mn-Ni-Si enriched with copper begins, which is a kind of catalyst for this process [5]. Because the concentration of these elements is low, precipitate emerge and grow very slowly $[6,7]$. Therefore, it is unnoticed long at the macroscopic level. And the dependence of $T_{K}$ on fast neutron fluence continues to be well described by $F^{1 / 3}$ law. Thus, welded metal reactor vessels with high nickel and manganese content have limited ability to be operated during the project beyond the design period. Other analyzed weld metals that characterize the state of the vessel exhibit much lower radiation embrittlement ratios, which, from the point of view of fragile strength, make it possible to extend the safe operation of the reactor vessel beyond the design period even up to 80 years.

\footnotetext{
*A1 - A6 - Ukraininan NPP units Legends
} 


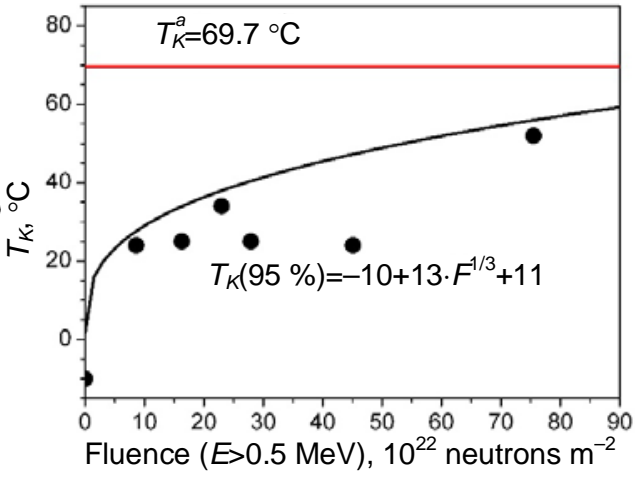

$a$

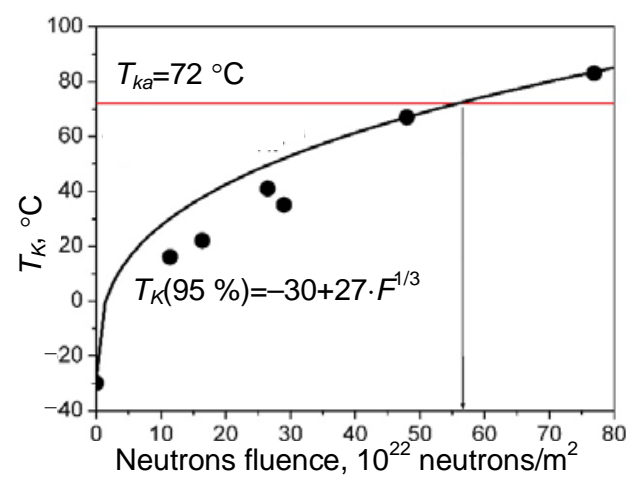

C

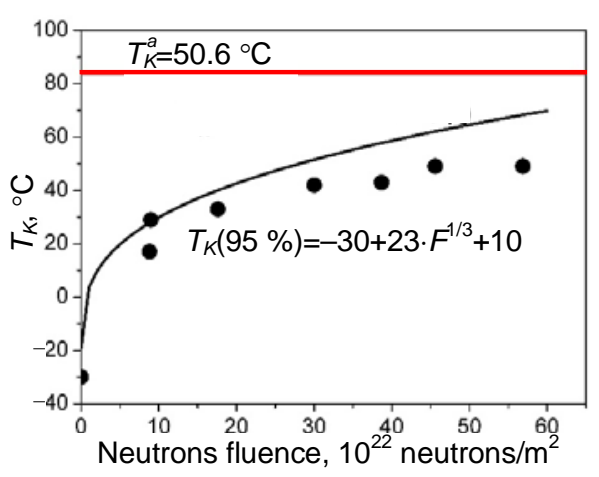

e

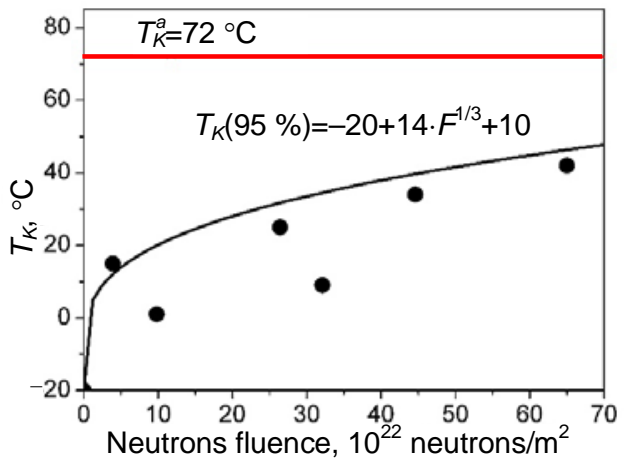

$b$

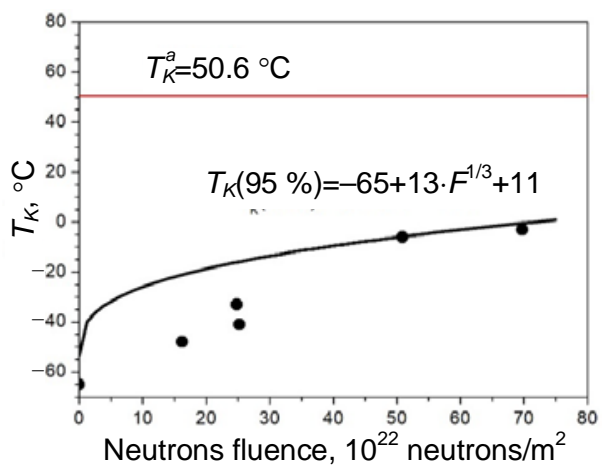

d

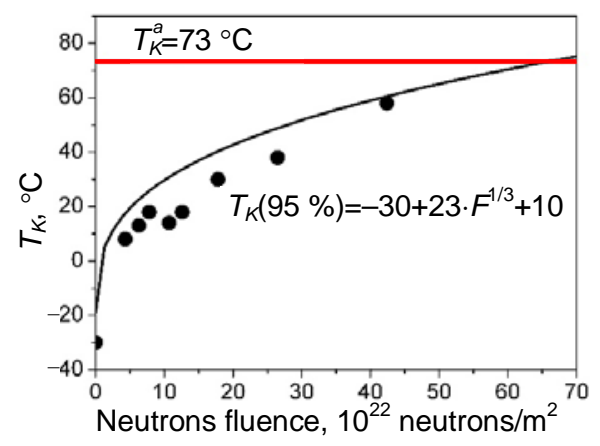

$f$

Fig.2. Comparison of the dose dependences of the critical brittleness temperature with the maximum allowable value $T_{K}^{a}$ : unit $A 1(a)$; unit $A 2$ (b); unit $A 3(c)$; unit $A 4$ (d); unit $A 5$ (e); unit $A 6$ (f)

\section{Conclusions}

An analysis of the results obtained for the metal of the six reactor vessels showed that if the reactor vessel wall accumulates fast $(E \geq 0.5 \mathrm{MeV})$ neutron fluence greater than $57 \times 57 \times 10^{22}$ neutron $/ \mathrm{m}^{2}$, there is no change in the shift of the critical brittleness temperature from the neutron fluence of at least $95 \%$ of confidence limit. This confirms the conclusion about the absence in the metal of WWER reactor noticeable rapid embrittlement under irradiation upto fast neutron fluence $\sim 80 \times 10^{22}$ neutrons $/ \mathrm{m}^{2}$.

Thus, the obtained results indicate the possibility of operating the reactor vessels in the beyond design period. The life-time extension will be carefully calculated for each reactor vessel separately. 


\section{Література}

1. Primary radiation damage: A review of current understanding and models / L. Malerba, K. Nordlund, A.E. Sand and other. Journal of Nuclear Materials. 2018. Vol. 512. P. 450-479.

2. On the thermal stability of late blooming phases in reactor pressure vessel steels: An atomistic study / L. Malerba, G. Bonny, D. Terentyev and other. Journal of Nuclear Materials. 2013. Vol. 442(1-3). P. 282-291.

3. ПНАЭ Г-7-002-86. Нормы расчета на прочность оборудования и трубопроводов атомных энергетических установок. М. : Энергоатомиздат, 1989. 525 с.

4. СОУ НАЕК 087:2015 Методика определения радиационного охрупчивания металла корпусов реакторов по результатам испытаний образцов-свидетелей. 2018. 29 с.

5. Eason E.D., Odette G.R., Nanstad R.K., Yamamoto T. A physically-based correlation transition temperature shifts for RPV steels. Jornal of Nuclear Materials. 2013. Vol. 423. P. 240-254.

6. Embrittlement of Reactor Pressure Vessel Steels under Extended Service Conditions: The Status and Implications of the UCSB ATR-2 Experiment / G.R. Odette, T. Yamamoto, R.K. Nanstad and other. 4th International Conference on Nuclear Power Plant Life Management Session 3-4 (presentation IAEACN-246-055). October 23rd - 27th, 2017 Lyon, France. P. 20.

7. Odette G.R., Nanstad R.K. Predictive Reactor Pressure Vessel Steel Irradiation Embrittlement Models: Issues and Opportunities. JOM, Materials Issues in Nuclear Reactor Overview. 2009. Vol. 61 (7). P. 17-23.

\section{References}

1. Malerba, L., Nordlund, K., \& Sand, A.E. et al. (2018). Primary radiation damage: A review of current understanding and models. Journal of Nuclear Materials, 512, 450-479.

2. Malerba, L., Bonny, G., \& Terentyev, D. et al. (2013). On the thermal stability of late blooming phases in reactor pressure vessel steels: An atomistic study. Journal of Nuclear Materials, 442(1-3), 282-291.

3. PNAE G-7-002-86. Standards for calculating the strength of equipment and pipelines of nuclear power plants. (1989). Moscow: Energoatomizdat, 525 p.

4. SOU NAYK 087: 2015 Methodology for the determination of radiation embrittlement of metal in reactor vessels according to the test results of witness samples. (2018). 29 p.

5. Eason, E.D., Odette, G.R., Nanstad, R.K., \& Yamamoto, T. (2013). A physically-based correlation transition temperature shifts for RPV steels. Jornal of Nuclear Materials, 423, 240-254.

6. Odette G.R., Yamamoto T., Nanstad R.K. et al. (2017). Embrittlement of Reactor Pressure Vessel Steels under Extended Service Conditions: The Status and Implications of the UCSB ATR-2 Experiment. 4th International Conference on Nuclear Power Plant Life Management Session 3-4 (presentation IAEACN-246-055). October 23rd - 27th, 2017 Lyon, France. P. 20.

7. Odette, G.R. \& Nanstad, R.K. (2009). Predictive Reactor Pressure Vessel Steel Irradiation Embrittlement Models: Issues and Opportunities. JOM, Materials Issues in Nuclear Reactor Overview. 61, 7, 17-23.

Голяк Микола Геннадійович; Holiak Mykola, ORCID: http://orcid.org/ 0000-0002-2662-4562

Ревка Володимир Миколайович; Revka Volodymer, ORCID: https://orcid.org/0000-0002-8409-263X

Чирко Людмила Іванівна; Chyrko Liudmyla, ORCID: https://orcid.org/0000-0002-7399-2309

Тригубенко Олександр Вікторович; Trygubenko Oleksandr, ORCID: https://orcid.org/0000-0002-2768-5121

Чайковський Юрій Віталійович; Chaikovsky Yuriy, ORCID: https://orcid.org/0000-0002-4692-1759 